\title{
Recent changes in mental health legislation and government policy in psychiatric care in Australia
}

\author{
Bernard Boerma, Robert Hayes, Alissa Moen \\ and Anthony T. Williams
}

There have been a number of recent changes in mental health care legistation in Australia some of which mirror the changes that have occurred in the UK. These are reviewed within the context of the difiering health care system in Australia and with particular relerence to the State of Now South Wales.

Australia provides a good setting for discussion of international legal issues. In 1770 it became a British penal colony. The anglophone common law legal systems of the States (there are six) and Territories (there are two), and of the Commonwealth of Australia, have been much influenced by concepts and approaches to shared social phenomena developed by American courts and legislatures.

Each State of Australia has had a series of laws governing mental illness. These laws trace their origins ultimately to the royal prerogative which, from feudal times, protected those with mental illness. The original commission issued to Governor Phillip in 1787, in the penal settlement which was to become the State of New South Wales, contained enlightened instructions applying English law relating to the protection of 'lunatics'. Since the advent of responsible government, in each of the States, numerous statutes have been progressively enacted. In each of the States and Territories, no matter how recent their latest Mental Health Act, governments, law reform bodies, and consumer organisations continue to be active in applying their minds to the issue of how things could be improved, in terms of formulation of policy and legislation, and development and delivery of services.

\section{Legislation and policy}

Behind all of this activity there are two seminal documents. The first is the United Nations statement of Principles for the Protection of Persons with Mental Illness and for the Improvement of Mental Health Care, and the second is the National Mental Health Policy and Plan which includes a National Mental Health Statement of Rights and Responsibilities. The twin policies of 'deinstitutionalisation' and the provision of integrated community-based services as an alternative to involuntary hospital care are, of course, strongly reinforced in these documents and are progressively being recognised among the objectives of recent or planned new legislation in the various States and Territories.

The most progressive of all of the States in acting quickly and effectively to enshrine the international and national principles in mental health policy, law, and administration has been New South Wales which recently passed its 1990 Mental Health Act, and which has been active since then in its monitoring and further revision. For example in 1994 amendments were passed to increase the effectiveness of the Act's novel community orders, which allow for mandated community treatment for persons whose chronic or acute illnesses would in the past have dictated their institutionalisation, possibly long-term.

While mental health legislation has traditionally, and constitutionally, been 
regarded as a State matter in Australia, in this, and other areas, international bodies, and the federal government, will have an increasing input. The justification for this derives from the federal parliament's constitutional 'external affairs' power which supports federal legislation implementing international treaties and obligations including obligations in the area of human rights. It is possible in a future Australia that we could have a federal Mental Health Act, which overrides those of the States. This raises issues similar to those being currently debated in Australia in the context of the federal government's proposal to override Tasmanian laws prohibiting homosexual acts with federal legislation implementing international guarantees of privacy protection.

In some States, most notably, Western Australia, the current legislation dates back to the 1960s and reflects out-of-date attitudes and approaches to civil rights and appropriate treatment of mental illness. All of those states with older legislation are now currently drafting more modern mental health laws.

A recent enquiry into the rights of the mentally ill by the Human Rights and Equal Opportunity Commission condemned the absence in the laws and programmes of some of the States of effective civil rights protections and community-based, appropriately-funded, integrated services. Following the enquiry, the federal government set up a Model Mental Health Legislative Consultancy. The consultancy issued a draft document for discussion by the key players in all of the States and Territories. The document is entitled Model Mental Health Legislation, a discussion paper (August 1994).

Those States with the most outdated legislation are holding back implementing their reform efforts until the consultancy settles some model legislation for consideration throughout the whole of Australia. On the other hand, South Australia now has new mental health and guardianship legislation. New South Wales, in addition to ongoing revision of the 1990 Mental Health Act, has made significant progress in the monitoring of community services, and professional accountability, through the Disability Services Act 1993, the Community Services (Complaints and Appeals Monitoring) Act 1993 and the Health Care Complaints Act 1993.

There is in Australia a growing emphasis on community-based care and the progressive movement of funding from the 'stand alone', large psychiatric hospitals to general psychiatric units and community health care agencies providing integrated services. There is a move towards limiting admission when necessary to the minimum time to restore stability in the psychiatric units in general hospitals. In other words, throughout Australia mental health law, policy, and administration are increasingly 'mainstreaming patients' and reflecting the so-called 'bio-psychosocial' model of treatment. The focus of public and consumer discussion is thus increasingly turning to the issues of the stigma attached to mental illness, the tendency of the mass media to stereotype those with mental illness and discrimination against the mentally ill, particularly in areas like housing and open employment.

Australia has been in the vanguard of western democracies providing sophisticated new administrative law mechanisms that will address the issue of discrimination against people with mental illness. Thus, on 26 July 1994, the Federal Equal Opportunity Commission, sitting in the State of Tasmania, awarded a Tasmanian man with a mental illness, $\$ 20,000$, in the first case under the Federal Disability Discrimination Act 1992. The States, in particular New South Wales, have been active in the discrimination area. The New South Wales Anti Discrimination Act was recently amended to make it illegal to discriminate against people because of mental illness.

\section{Implications of psychiatric practice}

The impact of national government policy, and evolving legislation, throughout Australia will increasingly be towards mainstreaming pursuant to the bio-psychosocial model for treatment of mental illness. Mentally ill people who before would have been housed in psychiatric institutions will increasingly be found living in secure, affordable, public housing. Private sector boarding houses and hostels will increasingly come under more regulatory control with watchdog agencies monitoring standards. People with special needs, such as children and adolescents, persons of non-English speaking background and women will find that special policies and services will be devised to fit their needs. Aboriginal people will continue to assert the need for special schemes and programmes, 
reflecting their culture and customary law. Governments will gradually come to recognise these claims.

\section{References}

Model Mental Health Legislation: a discussion paper. Centre for Health Law, Ethics and Policy. Untversity of Newcastle. August 1994

National Mental Health Policy and Plan. Endorsed by Australian Health Ministers. Canberra. April 1992.

National Mental Health Statement of Rights and Responsibilities. Adopted by the Australian Health Ministers, Canberra, March 1991.

Principles for the Protection of Persons with Mental Illness and for the Improvement of Mental Health Care. United
Nations, G.A. res 119, UNGAOR, 46th Sess, Supp. No. 49. Annex, at 188 to 92. U.N. Doc. A_/46/49 (1991).

BERNARD BOERMA, Registrar, Mental Health Review Tribunal; ROBERT HAYES, President, Mental Health Review Tribunal, PO Box B19, Boronia Park, NSW, Australia 2111; ALISSA MOEN, Research Assistant, Centre for Health Law, Ethics \& Policy, University of Newcastle, University Drive, Callaghan, NSW, Australia 2308; and ANTHONY T. WILLIAMS, Director, NSW Institute of Psychiatry, PO Box 2008, North Parramatta, NSW, Australia, 2151

\section{Prevention in Psychiatry}

\section{Edited by Eugene S. Paykel and Rachel Jenkins}

Prevention has made a major contribution to the control of many medical diseases. In psychiatric disorders its place has been problematic. This book seeks a balanced appraisal of the evidence and possibilities, and will be of interest to service planners, trainees and all mental health professionals. The chapters cover a wide range from general principles to approaches to specific disorders, age groups, speciality problems, and settings. The expert evidence gathered in the preparation of the original College policy document is discussed comprehensively, making this book essential reading for anyone concerned with mental health care.

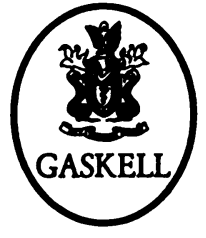

$\bullet £ 12.50 \bullet 215 p p . \bullet 1994 \bullet$ ISBN 0902241729

Available from the Publications Department, Royal College of Psychiatrists, 17 Belgrave Square, London SW1X 8PG (Tel. 0171-235 2351) 